\title{
How platforms facilitate collaboration across organizational boundaries: fighting human trafficking in Sweden
}

\author{
Josefina Erikson ${ }^{1} \cdot$ Oscar L. Larsson ${ }^{2}$ \\ Published online: 5 February 2020 \\ (c) The Author(s) 2020
}

\begin{abstract}
The use of collaborations and partnerships that engage a variety of actors from both the public and private spheres has drawn attention during the last decade as a promising strategy for combatting trafficking and improving assistance to victims of trafficking. This article investigates the Swedish Civil Society Platform against Human Trafficking as an example of successful collaboration between civil society actors. The aim is to explore how the platform as a distinct organizational form is capable of dealing productively with some of the challenges facing internal and external collaboration. We utilize interviews with key actors and a study of policy documents as we argue that the modularity and flexibility of the platform organizational form are key factors in its success. While it is a robust type of organization that may be regarded as a trustworthy partner, it also permits its member organizations to continue functioning as independent entities.
\end{abstract}

Keywords Civil society $\cdot$ Collaboration $\cdot$ Platform $\cdot$ Wicked social problems $\cdot$ Publicprivate relations

\section{Introduction}

Collaborations and partnerships that involve a variety of actors from different sectors have come to be regarded during the last decade as promising means to combat trafficking and support the victims of trafficking (Foot 2015; Lagon 2015; Wagenaar et al. 2017; Jones and Lutze 2016). The Swedish Civil Society Platform against Human Trafficking has recently emerged as an example in this regard of successful collaboration among civil society actors. This collaboration has not only enhanced coordination between different types of volunteer organizations, thereby rendering support for victims more effective, it has also developed a public National Support Program (NSP) to provide economic aid to victims and served as an active partner of public agencies. Although research has shown

Josefina Erikson

josefina.erikson@statsvet.uu.se

Oscar L. Larsson

oscar.larsson@fhs.se

1 Department of Government, Uppsala University, Uppsala, Sweden

2 War Science, Marine Section, Swedish Defence University, Stockholm, Sweden 
that potential challenges are associated with all forms of collaborative undertakings, both civil society and public agencies describe the new platform model of collaboration in overwhelmingly positive terms. The aim of this article is to explore how this organizational form is capable of successfully dealing with some of the challenges facing collaboration, with a particular focus on two such issues related to the Swedish case. These are first, how does the platform structure promote collaboration between its member organizations? and second, how does the platform organization facilitate collaboration with public agencies while retaining the critical voice of civil society organizations?

Trafficking is a multifaceted problem, and engaging with the victims of trafficking is itself a demanding task insofar as victims are often in need of multiple forms of assistance from a number of different public agencies, including social and medical services, the police, and prosecutors (Chang and Kim 2007). Trafficking constitutes a "wicked" social problem insofar as no single actor can decisively address it, with the phenomenon itself being based upon cross-border and cross-jurisdictional activities. In additional, victims of trafficking are often unaware of their rights and fear both traffickers and law enforcement agencies. Civil society organizations have thus become indispensable actors in this complex situation not only because victims tend not to trust public agencies, but also because states seem incapable of extending welfare assistance to undocumented migrants, even when they are victims of serious crimes (Aronowitz 2009:10; Clear et al. 2018).

Scholars have extensively debated how various forms of collaboration could facilitate efforts to address and manage such wicked problems as prostitution and trafficking (Weber and Khademian 2008; Torenvlied et al. 2013; van der Heijden and Schalk 2018; Cristofoli et al. 2017; Ferlie et al. 2011). It has also been argued, however, that loosely formulated collaborations and spontaneous networks introduce a set of significant problems, not the least of which are organizational fragility, least common denominator outcomes, collaboration fatigue, and even deadlock (Ansell and Gash 2017:2; Huxham and Vangen 2013; Klijn and Koppenjan 2016). Much of the analysis of collaboration and networks has focused on public administration, however, and it has not fully addressed the challenges that civil society organizations (CSOs) encounter as they engage in collaborative efforts in the pursuit of shared goals. We maintain that, from a civil society perspective, challenges concerning both internal and external collaboration need to be managed if collaboration between CSOs is to be successful.

The particular focus of our investigation is the Swedish Civil Society Platform against Human Trafficking (hereafter the Platform), which comprises a diverse set of NGOs that came together in 2013 as a response to the Council of Europe's evaluation of Sweden in that same year. The Platform is unusual not only because of its organizational form, which is something between a loosely coupled network and an organization proper, but also because it hosts such diverse organizations as The Salvation Army and the radical feminist group ROKS (National Organisation for Women's Shelters and Young Women's Shelters in Sweden), which work side by side and share a "victims-first" agenda. In brief, we will seek to evaluate the opportunities and challenges regarding internal and external collaboration that are associated with the platform format through an in-depth case study of an organization, operating within the demanding policy area of trafficking, that has been consistently portrayed as successful. This will provide insights concerning how the platform organizational form as such can serve as a basis for coalitions and collaborations that are of value in other contexts as well.

On the basis of our findings, we argue that the modularity and flexibility provided by the Platform through its fairly broad "victims-first" agenda are key factors for its success. In addition, its graded membership policy facilitates internal collaboration and flexibility 
insofar as its member organizations can choose their level of engagement in various activities while also continuing to act as independent organizations. Finally, the fact that the Platform serves as a unified actor makes effective external collaboration possible, including close relations with public agencies, while individual member organizations are left free to maintain their critical voice.

\section{Anti-trafficking collaboration}

Previous research concerning trafficking is diversified, being oriented toward such differing facets of the problem as legal studies (Halley et al. 2006; Guild 2006; Gallagher 2010), crime prevention and criminology (Goodey 2008), feminist studies (Outshoorn 2005; Levy and Jakobsson 2013; Hughes 2004), health care for victims (Baldwin et al. 2011; Lederer and Wetzel 2014; Ahn et al. 2013), and social work (Hodge 2008; Kotrla 2010; Jones et al. 2007). These studies have not adequately examined anti-trafficking efforts that utilize collaborative governance or partnership initiatives, and they have not explored the role of civil society in resolving this problem. Their focus has rather been directed toward identifying individual victims' needs, or on the role of social workers. During the last decade, however, an emergent body of literature has directed attention toward collaborative anti-trafficking efforts of various types and begun investigating the roles of civil society actors, public agencies, and businesses in this regard.

Jones and Lutze, for example, examined collaboration between public agencies in the State of Michigan. They found that in spite of the many benefits of collaboration in the struggle against trafficking, most agencies had only limited involvement in relevant interagency collaborative activities (Jones and Lutze 2016). Davy (2013a, b) investigated the motivations and activities of transnational advocacy networks against child sexual exploitation along with the effectiveness of such initiatives. Her findings show that these networks have had significant progress in the Mekong Subregion in bringing the issue of child trafficking onto the global social policy agenda. In another pertinent study of partnerships opposing human trafficking, Lagon has identified eight areas of importance for successful public-private partnerships, in which he places a priority on the identification and care of victims (Lagon 2015). Although he has emphasized the importance of involving NGOs in such activities, he does not discuss in detail how such collaboration can be arranged.

Foot (2015) has conducted an extensive study of collaborative partnerships in the struggle against trafficking that involve both public and private actors from differing areas of activity. Her starting point is that collaborations can be successful in this work, but she also highlights some of the challenges that must be overcome. These include potential conflicts of interest between given organizations and the overarching aims and goals of the partnership; the power dynamics between partners, such as those obtaining between NGOs and public agencies; and the difficulties that may arise when both faith-based organizations and "areligious" organizations participate in the same collaborative framework (Foot 2015:21). While Foot presents practitioners with a list of tools for improving collaboration, some of her findings also point to further lines of inquiry in this area, such as how power dynamics appear within various collaborative efforts and whether a particular collaborative style may influence group power dynamics.

Briefly stated, research has recently begun to explore both the advantages and shortcomings of collaborative anti-trafficking efforts. This article endeavors to contribute new knowledge concerning collaboration among civil society actors in this regard and explore 
the platform organization as a particular type of collaborative arrangement, upon the basis of an investigation of the Swedish Platform against Human Trafficking.

\section{Platforms, multidimensional collaboration, and associated challenges}

Collaborative efforts may be formalized in a variety of ways that range from contracted public-private partnerships (PPPs) to loosely composed networks (Steijn et al. 2011). Collaboration between public and private actors may generate substantial problems regarding coordination, however, and generate insoluble conflicts (Huxham and Vangen 2013; Klijn and Koppenjan 2016). For example, research has revealed how obstacles to internal coordination and difficulties in handling real-world conditions can emerge in loosely defined selforganizing networks (Kania and Kramer 2011). Others have argued that it is not the given organizational form itself, but rather the new managerial approaches that have been implemented within public-private partnerships that have led to improved outcomes (Steijn et al. 2011; Ysa et al. 2014).

While numerous studies have addressed both the advantages and shortcomings of utilizing collaborative networks in dealing with public problems (Klijn and Koppenjan 2016; Verweij et al. 2013), we believe that more attention must be directed to how CSOs can organize themselves in a way that not only promotes coordination between such organizations, but also provides leverage in relation to public authorities. It has previously been shown that convergence within civil society can add capacity, synergy, and voice to efforts aimed at addressing "wicked problems" and also provide a basis for public-private collaboration (Magis 2010). However, the fact that CSOs display a great degree of heterogeneity regarding their types of organization and purpose can hamper building coalitions not only between public authorities and nonprofit organizations, but between CSOs as well (Willems et al. 2017). In addition, although it can be difficult to create coalitions between social-activists movements, such coalitions once forged provide civil society activists with increased leverage (Chemin and Vercher 2011). In this respect, collaborative platforms may facilitate cross-organizational collaboration while also creating a basis for convergence and coalition-building that enhances the ability of CSOs to enter into public-private relations without being co-opted.

Ansell and Gash have recently argued that collaboration organized by means of a platform constitutes a specific organizational form that possesses the potential to both catalyze and sustain volunteer efforts in an efficient manner. Not only does this type of organization provide a structured framework that facilitates a varied set of collaborations between ranges of organizations, it also maintains the diversity that a single organization typically lacks (Ansell and Gash 2017:2). The basic characteristic of a platform is that it brings together a number of differing organizations that nevertheless share a common agenda (Selsky and Parker 2005), such as when NGOs work together to improve the environment or, as in our case, provide care for the victims of trafficking. A platform is often a standalone organization, but it may also comprise a program or sub-unit of a larger structure that includes organizations as well as public authorities and individuals (Ansell and Gash 2017:5). While networks are "self-organizing," "loosely coupled," and potentially consist of horizontal relations between autonomous organizations (see Rhodes 1996), the key feature of a platform is that it is more structured than a network, but less tightly ordered than an organization in the strict sense. It is also important to note that networks exist only through their actual and ongoing relations with other organizations. Stated otherwise, a 
network is not a judicial entity, often has no administrative center, and ceases to exist if its relational activities stop.

A coalition or goal-directed network with a common aim may thus suffer from not being formalized as a judicial entity and fail to establish a unified organizational structure, that is, a membership-based platform for its partners in collaboration (see Provan and Kenis 2008). In contrast, a platform provides a more strict organizational form that is capable of resolving challenges associated with various forms of collaborative arrangements by virtue of its distinctive characteristics. These will be addressed in greater detail below. Merely using the term "platform" to brand, a given collaboration does not determine its status and functionality, which instead depend on the unique characteristics of its organizational format.

\section{The Swedish platform against human trafficking}

Sweden has been discussed internationally as a role model in efforts to combat trafficking because of its 1998 ban on prostitution that criminalizes the purchase, but not the sale, of sexual services (Skilbrei and Holmström 2017; Cho et al. 2014; Erikson 2017). Although this policy does not explicitly targeting trafficking, it has been discussed as a measure for cutting the demand for sexual services that would thereby comprise a means for combating trafficking as well (Skr. 2007/08:167:3). ${ }^{1}$ Sweden adopted a national legislation that bans trafficking in 2002, later revised in 2004 and $2010 .^{2}$ In addition, a collaborative governance strategy has emerged during the last decade aimed at improving the identification and support of victims of trafficking. ${ }^{3}$

The Swedish Civil Society Platform against Human Trafficking, which was founded in 2013 by the independent trafficking expert Ninna Mörner, is an important element of this recent collaborative development. The Platform was initially formed to provide input to the Europeans Council's expert evaluation (GRETA) of Sweden in respect to trafficking, but it also comprised a response to the lack of NGOs engaged in this policy area and the country's inadequate support for victims of trafficking. The Platform, which began as a loosely coordinated network of organizations involved in anti-trafficking efforts, became a long-term collaboration with the specific aim of fostering coordination within civil society in this policy sector and improving support for victims.

The Platform has brought together approximately 20 CSOs engaged in combating human trafficking that possess a broad variety of orientations-humanitarian organizations, women's shelters with a clear feminist agenda (e.g., ROKS), and faith-based organizations (e.g., The Salvation Army). Together, they address the entire chain of assistanceidentification of victims, first aid, medical care, clothing, financial support, trauma care, legal advice, long-term assistance, safe return, and integration. Although the Platform has been assigned responsibility for a number of public tasks since its establishment in 2013, it is an independent organization that does not rely upon public funding for its operations. The Platform organizes open events or membership meetings on a monthly basis on various topics related to its agenda, and it cooperates with authorities on the local, national,

\footnotetext{
1 Handlingsplan mot prostitution och trafficking [Action Plan against Prostitution and Trafficking]. Regeringens skrivelse 2007/08:167, p. 27.

2 Brottsbalken [Swedish Penal Code], SFS 1962:700, Chapter 4.

3 Handlingsplan mot prostitution och människohandel för sexuella ändamål [Action Plan against Prostitution and Trafficking for Sexual Purposes]. Regeringens skrivelse 2007/08:167, p. 8.
} 
and regional levels with the aim of strengthening dialogue and cooperation in respect to the needs of the victims of trafficking. ${ }^{4}$ The member organizations of the Platform work on a daily basis to identify and support victims of trafficking, while the Platform itself serves as a hub for internal information exchange, facilitates coordination between its members in order to improve support for victims, and provides a channel for external communication and coordination between its members and public agencies. For example, the Platform presented a series of seminars during 2018 for its members and outsiders on such topics as "The Gender Dimension in Trafficking," "The National Support Program," and "Children in Trafficking." It has also participated as an expert on trafficking in courses and workshops arranged by public agencies and NGOs, in various evaluation reports, and in the media. In addition, it has assisted 42 persons through the National Support Program (NSP) with shelter and with support for empowerment and integration. ${ }^{5}$

This Swedish Platform serves to illustrate how the specific platform structure can facilitate coordination and collaboration among CSOs and between civil society and public authorities as well. It comprises a key instance of collaboration in the sense that trafficking is a particularly demanding and complex policy area.

\section{Methods employed}

The informal character of collaborative governance arrangements is such that gaining an understanding of a given organization typically requires contextual and qualitative knowledge that is best obtained through in-depth case studies. Consequently, we have conducted a detailed analysis of the Platform in order to explore how it operates and what its members and other actors view as the merits and weaknesses of this organizational format. The analysis is based upon policy documents, statutes, public reports, other printed material from the Platform and its member organizations, and Web pages. We also conducted 13 interviews during autumn 2017 that complement the written data with information regarding how the Platform functions in practice, how it manages and delivers criticism of public authorities, and how it deals with conflicts. We interviewed representatives of six of the Platform's approximately 20 organizations, several of whom are board members, and we sought to include different types of organizations in the sample, such as religious and women's organizations and law firms. In addition, we interviewed three representatives of public agencies who work closely with the Platform and two representatives of organizations that work with trafficking or related issues and are not members of the Platform. Our intent was to gain a balanced and unbiased understanding of the Platform from both inside and outside the organization.

The interview questions initially centered on general issues, such as the aims of the Platform, its work in practice, and its relation to public agencies. We explicitly raised questions near the end of each interview concerning problems with internal coordination that may arise within a platform and possible challenges in external coordination, including how to maintain a critical voice while working with public agencies. All respondents were asked to actively give their consent after we had explained the purpose of the project. We also

\footnotetext{
4 The Platform, https://manniskohandel.se/plattformen-civila-sverige-mot-manniskohandel/samarbetet -i-plattformen/.

5 The Platform, https://manniskohandel.se/plattformen-civila-sverige-mot-manniskohandel/samarbetet -i-plattformen/, accessed 2019-11-19.
} 
permitted each informant to read the final transcript of their interview in order to avoid any possible misunderstanding on our part. The respondents, none of whom requested that we conceal their identity, are all semipublic figures in the given policy field.

We utilized a two-step analytical approach, described below, in which we first explored internal collaboration in respect to organizational structure, agenda, and conflict management, specifically focusing on how the Platform deals with challenges associated with its diversified membership. We then, in the second step, examined external collaboration in respect to public policy making, public control, and advocacy. We particularly focused on how the Platform managed the challenge of maintaining its critical voice while also being a trustworthy partner of public agencies. We employed a process of triangulation in our analysis, utilizing several different sources to substantiate our findings.

It should be noted that the analysis focuses on the period from 2013 through 2018, that is, prior to several organizational changes introduced by the Swedish Government that include granting the newly established Gender Equality Agency a prominent role in this policy field. While no further organizational or ideological changes have been announced, it remains to be seen whether and how the collaborative governance arrangements that we examined evolve and are managed in the future.

\section{An analytical approach to critically assessing the challenges facing collaborative platforms}

The platform organizational structure is marked by the modularity of its architectural design, which alters the mode of managerial control. This makes it possible to combine resources as well as members' ambitions and interests in a manner that enhances internal collaboration and coordination (Furlan et al. 2014). It also introduces a level of flexibility that can foster exchange, synergy, and positive feedback among member organizations, which mutually benefit from their respective contributions (Ansell and Gash 2017:4; see also Nambisan 2009). While existing studies of collaborative platforms have focused primarily upon internal coordination (see Clear et al. 2018), we investigate their potential for external collaboration with other organizations, including public agencies. The dimensions of internal and external collaboration are developed in greater detail below.

\section{Managing a diverse membership in internal coordination and collaboration}

An important issue regarding internal coordination concerns whether a given platform is voluntary or statutory in character (Boudreau 2010; Steins and Edwards 1999:244). Networks, coalitions, and advocacy alliances provide examples of volunteer platforms (Mati 2009). In contrast, platforms that are statutory in character comprise judicial entities, and they must codify their membership, procedures, purpose, and organizational structure. They may also include an appointed or elected board or working committee who manage the platform and are responsible to the membership.

Scholars have recognized the paradox that obtains between collaboration and leadership, and they have begun exploring nonhierarchical leadership styles in the effort to identify how a new type of collaborative leadership can be fostered (Ysa et al. 2014). This type of leadership would be important for both voluntary and statutory platforms. Although voluntary platforms resemble loosely coupled networks, they still advance cooperation by making it possible for a variety of organizations with differing competences and interests to 
join forces for a common purpose. Yet such loose coupling of organizations are potentially fragile and conflict-prone arrangements.

Membership and internal coordination are conditioned in both types of platforms by the agenda and the shared goals of the collaboration (Ansell and Gash 2017). While a broad agenda makes possible cooperation with a wider range of individuals and organizations, including those with competing interests and ideals, this may also give rise to conflicts regarding the basic purpose and orientation of a given platform that leads to fragility (Boudreau 2010). In contrast, strict agendas and clearly defined goals tend to make partnerships more effective, but they can make an organization closed and too narrowly focused, which would exclude alternative perspectives and new insights concerning the issues they address as well as the possibility of building a broader and more inclusive coalition of actors. In short, platforms require strategic management of their internal coordination and collaboration, along with careful decision making regarding their organizational form in relation to their agenda (Chemin and Vercher 2011; Steijn et al. 2011).

Conflict management is a third important factor regarding internal coordination within organizations that consist of a diversified set of member organizations. One potential strength of platforms is their modularity and flexible mode of operation, whereby they are particularly appropriate for addressing constantly changing problems that tend to elude fixed solutions. Although a varied coalition of member organizations provides certain advantages in respect to getting everyone on board and minimizing opposition, it also runs the risk of internalizing conflicting interests, hindering internal work, and limiting possibilities for acting externally. Internal disagreements regarding the purpose and agenda of a given platform may make it difficult to conduct external joint activities, including raising awareness, influencing public policy makers, caring for victims of trafficking, writing reports and op-eds, and managing programs (Ciborra 1996; Klijn et al. 2010). For this reason, an important element of efficient internal coordination involves mediating between the competing values, interests, and opinions that risk undermining the activities and goals of a given platform.

Briefly stated, internal collaboration involves a number of issues that must be balanced in order for a given platform to manage a diverse membership in a way that is conducive to attaining its goals. Previous research on anti-trafficking collaborations has identified a number of challenges related to internal coordination, such as conflicts of interests between member organizations' individual agendas and overarching shared agendas as well as power dynamics involving member organizations and/or partners (Foot 2015:21).

\section{Managing relations with public agencies in external coordination and collaboration}

Civil society platforms operate within a web of policy makers, legal frameworks, and traditional public administration. They must also take into consideration other local collaborations, networks, and organizations that are potential partners or adversaries regarding the particular agenda being pursued (Andrews et al. 2011). An important issue in this respect involves the need for multilevel mediation between public and private actors on the local, national, and international levels (van der Heijden and Schalk 2018).

Involvement in defining public policy constitutes a significant issue in evaluating how a given platform handles relations with public actors insofar as it can either lead to significant political influence, or undermine the credibility of a given CSO. Another factor important for determining the character of a platform's external collaboration is its involvement in activities associated with public control. Civil society platforms typically rely upon the 
voluntary contributions of independent organizations, and they rarely exercise the degree of power and authority necessary to exercise control over either their members or external actors (Ansell and Gash 2017:8). When a given platform does in fact become engaged in both policy making and public control, it acquires the opportunity to pursue its agenda and attain its goals in a more efficient way. However, becoming a close partner of public agencies may also threaten a platform's independence. It is therefore important to take into consideration the manner in which platforms manage their advocacy role in external collaboration. CSOs must preserve and exercise their critical voice in relation to current political policies and solutions (Larsson 2019), but they also risk cooptation (O'Toole and Meier 2004) and may be tempted to remain silent in order to ensure access to resources and informal influence in policy making and implementation (Clear et al. 2018).

A platform provides a crucial link between regulation by public authorities upon the basis of legal frameworks and the contributions of civil society actors, and this can both enhance operational capabilities and bring about greater proximity to target groups (Abbott et al. 2017; Black 2008; Carter and Mahallati 2017; Erikson and Larsson 2019). But if platforms become too involved with public agencies, they can lose the trust of citizensincluding such third parties as the victims of trafficking. The challenges related to power dynamics between public agencies and CSOs have been pointed to as potential pitfalls in previous research concerning public-private anti-trafficking collaborations (Foot 2015; Lagon 2015).

Our empirical investigation of the Swedish Civil Society Platform against Human Trafficking, in which we evaluate how it deals with challenges regarding various dimensions of internal and external collaboration, is shaped by the theoretical discussion we have presented above. We will focus in detail on the following:

1. The internal dimensions that will be investigated are organizational structure, agenda, and conflict management.

- We examine how the Platform handles the diverse character of its membership.

2. The external dimensions that will be explored are public policy making, public control, and advocacy.

- We investigate how the Platform balances maintaining its critical voice with being a trustworthy partner of public agencies.

\section{Empirical case study}

\section{Background and context of the platform's activities}

The activities of the Platform are described in overwhelmingly positive terms by both its member organizations and external actors. Collaboration between interest groups existed prior to its establishment, but there had been little collaboration and few coordinated antitrafficking efforts and initiatives within civil society before the creation of the Platform in 2013. Ninna Mörner, who served as Platform Coordinator from its inception through 2018, notes that civil society actions against human trafficking were previously fragmented, stating that "most of the organizations involved knew of each other, but had never met in 
person." ${ }^{\circ}$ Mörner claims that the benefits provided by a more coherent collaborative forum have been obvious.

It [trafficking] is a complex issue, but most actors have little knowledge and information about the legal framework and what others are actually doing.... In the end, the lion's share of the efforts undertaken to help victims are done by civil society actors. ${ }^{7}$

This positive view is supported by another respondent who maintains that the platform organizational form has fostered more efficient coordination and collaboration among a broader set of NGOs with differing aims.

Before the Platform was established, collaboration took place in smaller groups and depended on personal relations. The Platform creates a larger arena for action, which makes possible a broader range of coordination and collaboration beyond one's own personal network. ${ }^{8}$

Another advantage concerns the mutual exchange of competences. ${ }^{9}$ One interviewee observed that "Help is only a phone call away because of the Platform. We have gotten to know each other well, and there is no loss of prestige in asking for assistance." 10 Specialization is an important result of the increased coordination that the Platform provides insofar as the participating NGOs have acquired specific skills and resources in their independent activities that they can put to more efficient use through the Platform. While several organizations had previously offered similar services, such as legal assistance, the Platform has enabled them to share their capabilities in an optimal way. ${ }^{11}$ The Platform has also been recognized as a "forum for sharing experiences as well as a place to go to for immediate relief and assistance." ${ }^{\prime 2}$ Rather than acting as rivals, member organizations have been able to coordinate their activities such that they assist each other with the ultimate aim of improving support for victims, one example being that shelters for women exposed to trafficking can specialize in different categories of victims. In general, internal collaboration within the Platform works in a way that clearly facilitates the work of protecting and supporting victims of trafficking.

The Platform has been successful in advancing its agenda and attaining its goals regarding external collaboration as well. Patrik Cederlöf, the former National Coordinator of activities for combating prostitution and trafficking, maintains that public collaboration with civil society has in fact significantly improved since the establishment of the Platform insofar as civil society now speaks with one voice, not with the many voices of dozens of separate organizations and experts. ${ }^{13}$

The previous lack of collaboration with civil society was a point of major criticism in the 2013 evaluation conducted by GRETA, the expert group of the Council of Europe Convention on Actions against the Trafficking of Human Beings. As noted above, this was

\footnotetext{
6 Ninna Mörner, Platform Coordinator 2013-2018, interview 1, conducted September 1st, 2017.

7 Ninna Mörner, interview 1.

8 Madeleine Sundell, Salvation Army, Platform Board Member, interview conducted October 10th, 2017.

9 Ninna Mörner, interview 1.

${ }^{10}$ Isabella Kim, Ecpat, Platform Board Member, interview conducted November 1st, 2017.

11 Karin Gyllenring, interview.

12 Madeleine Sundell, interview.

13 Patrik Cederlöf, interview.
} 
a primary reason for why the Platform was launched. ${ }^{14}$ Since its establishment in 2013, the Platform has proven to be a key partner in efforts to rectify this problem by virtue of its participation in policy making, the management of specific programs, the collection of statistical data, and mediation in individual cases. ${ }^{15}$ This engagement has also made possible improved support for victims of trafficking, with the National Support Program (NSP), which the Platform developed and manages, ensuring that Sweden now fulfills its international obligations in this regard. The former national coordinator described the Platform's contributions as "indispensable," 16 and this view was supported by a public development coordinator working in the field of trafficking who stated that "Many times civil society steps in when public agencies should do so.... Civil society has taken on a growing role in these issues." 17 External collaboration has thus successfully supported the Platform's agenda, and expanded cooperation with public agencies has clearly resulted in improved assistance for trafficking victims by means of public programs.

We will now examine more closely how the Platform deals with the challenges it encounters in internal and external collaboration.

\section{The platform's internal collaboration: handling the challenges of diversity}

\section{Organizational structure}

The Platform's organizational structure has a significant impact on how it manages the diversity of its membership. While the structure was initially open in character, it officially became a statutory organization in 2017 consisting of approximately 20 NGOs and individual experts. The board elected at the constituting meeting, which was also its first annual meeting, included seven members under Mörner's leadership. ${ }^{18}$ Although the Platform has been given responsibility for several public undertakings since its establishment in 2013, it is an independent organization that does not rely on any public operational funding.

The decision to become a formal organization was motivated primarily by external circumstances insofar as several advantages were associated with the Platform's change in juridical status, such as being able to enter into contractual relations with Swedish public authorities and applying for supplementary public funding. However, this gave rise to a number of new challenges regarding its internal coordination, including being obligated to formalize and codify its structure, membership, and agenda; clarify statutes concerning decision-making procedures and the election of a steering committee; and publish annual reports regarding planned activities, results attained, and related matters. This was also coupled with the desire to have differing types of organizations represented on the board. Such changes demanded much closer coordination between the Platform's members than had previously been the case with the organizations involved, which heightened the

\footnotetext{
14 GRETA, report 2014:11, page 55.

15 The Platform, https://manniskohandel.se/plattformen-civila-sverige-mot-manniskohandel/samarbetet -i-plattformen/, accessed 2017-12-20; Madeleine Sundell, interview.

${ }^{16}$ Patrik Cederlöf, interview; Endrit Mujaj, Development Coordinator, County Administrative Board in Stockholm, interview conducted September 5th, 2017.

17 Endrit Mujaj, interview.

18 The Platform, https://manniskohandel.se/plattformen-civila-sverige-mot-manniskohandel/om-oss/, accessed 2017-12-20. It should be noted that the Platform selected Madeleine Sundell from the Salvation Army as their new Chairperson in 2019.
} 
possibility that latent internal differences or power dynamics could become a source of conflict. Against this background, it is noteworthy that becoming a statutory organization proceeded in a rather unremarkable fashion, as our interviews reveal. A number of the Platform's representatives even stated that they could barely remember the meeting at which the board and the statutes were approved, even though there had been a previous statutory call for nominations. ${ }^{19}$

Our respondents regard Mörner as both a competent and neutral chairperson and express their support for her. She has extensive experience as an independent expert in combating human trafficking and possesses a robust personal network, but is not a member of any specific organization. ${ }^{20}$ Mörner believes that her independence not only has been an important prerequisite for bringing together a diverse group of NGOs, it made it possible for her to assume the leadership role in the Platform. ${ }^{21}$

The formal regulations which have been put in place that allow for three types of membership comprise another important organizational issue. First, full membership is available to nonprofit organizations that support the goals and framework specified in the Platform's bylaws. Full members have the right to speak, nominate, and vote at annual meetings. Second, individual membership is available to experts and engaged actors who accept the Platform's statutes. These members are not permitted to nominate or vote at annual meetings. Third, affiliated membership without the right to vote at annual meetings is available to other organizations, foundations, and individuals who support the agenda of the Platform and wish to collaborate in its activities. ${ }^{22}$

The Platform conducts two basic types of regular activities. The first consists of regular board meetings, which plan activities, manage the National Support Program (NSP, discussed below), and make other relevant decisions. The second includes thematic events, workshops, and seminars, to which various members are invited. ${ }^{23}$ The Platform also serves as a resource hub that mediates contacts in individual cases so that either its member organizations or public agencies can provide victims of trafficking with the assistance needed. The board carry out a large part of both strategic and daily activities, with the remainder being undertaken by the various other members.

Our findings indicate that while the Platform's statutory change had positive implications for external collaboration, it has not had a significant impact upon the composition of its membership and on how diversity is handled. The graded membership has made it possible both to carry out the Platform's activities with a core of very active organizations that fully share the agenda and to maintain a broader network of more loosely affiliated organizations. This preserves the benefits of diversity while also elevating the level of organizational efficiency. In addition, the Platform's neutral leadership appears to have played an important role in avoiding conflicts of interest between organizations. All of the interviewees praised Mörner for her professional leadership, and none noted any controversy concerning her leadership or management. Controversial or biased leadership on the part

\footnotetext{
${ }_{19}$ Madeleine Sundell, interview; Wiveca Holst, ROKS [National Organisation for Women's Shelters and Young Women's Shelters in Sweden], Board Member, interview conducted November 17th, 2017.

${ }^{20}$ Madeleine Sundell, interview; Isabella Kim, interview.

21 Ninna Mörner, interview 1.

22 The Platform, https://manniskohandel.files.wordpress.com/2015/12/stadgar-plattformen-2017-antgna-31mars.doc, accessed 2018-02-19.

23 Ninna Mörner, interview 1 and interview 2, conducted November 28th, 2017.
} 
of any of the stronger organizations could potentially lead to friction and conflict instead of collaboration.

\section{Agenda and framework}

The Platform is described on its Web site as a human rights-based nonprofit organization that is focused on combating human trafficking and restoring the dignity of victims. Its activities reside upon a "victims-first" principle that involves the recognition of individual worth and the implementation of empowerment strategies. ${ }^{24}$ The Platform thus directs many of its undertakings toward victims of trafficking, but it also supports the Swedish model of criminalizing the purchase of sexual services. ${ }^{25}$

The "victims-first" agenda is broad enough to bring together a variety of organizations that have competing and potentially conflicting programs. For instance, the Platform includes radical feminist as well as Christian faith-based organizations that agree upon one and the same perspective concerning victims even though they are potentially at odds in other respects. The respondents relate how the members have so far found a way in which to put their differences aside and work toward a common goal. ${ }^{26}$ The Chairperson in fact maintains that "diversity in ideas and practice is a core strength of the Platform." 27

The Swedish model of criminalizing the purchase of sex is a controversial issue that, in spite of a strong support, has been questioned in academic and political debates on both normative grounds (Dodillet 2009; Showden and Majic 2014) and in respect to its effects upon trafficking (Cho et al. 2014; Weitzer 2011). Although caring for victims serves to unite a broad range of CSOs - this humanitarian agenda is hardly controversial - the policy of client criminalization serves to restrict membership. For example, although the Platform does not rule out cooperation in individual cases with organizations that do not share their normative stance in this regard, ${ }^{28}$ there is a certain probability that organizations that provide services for sex workers and/or do not support client criminalization may not be able to become full members. One example is the Rose Alliance, an organization that defends the interests of sex workers within a pro-sex-work framework. While the Rose Alliance believes that there are potential grounds for collaborating with the Platform insofar as they come into contact with many possible victims of human trafficking, they maintain that they have never been invited to join. Their Chairperson, Pye Jakobsson, regards this as somewhat remarkable since the Rose Alliance clearly recognizes that sex workers can be victims of trafficking. Jakobsson maintains that "It is a shame that we have not been invited. If nothing else, we could contribute by providing useful information." 29 Although the Platform's Coordinator remarks that cooperation with such organizations is very unlikely, claiming that "They would not be interested," she nevertheless maintains that there are no obstacles to providing support and help in individual cases. ${ }^{30}$ Although the Platform has

\footnotetext{
${ }_{24}$ The Platform, https://manniskohandel.se/plattformen-civila-sverige-mot-manniskohandel/mal-och-varde grund/, accessed 2017-12-20.

25 Ibid.

26 Wiveca Holst, interview.

27 Ninna Mörner, interview 2.

28 Ninna Mörner, interview 1.

29 Pye Jacobsson, Chair, Rose Alliance [Swedish National Organization for Sex Workers], interview conducted November 24th, 2017.

30 Ninna Mörner, interview 2.
} 
collaborated with organizations that do not fully share their agenda on a number of occasions, including Médicines Sans Frontiers and the Swedish Federation for Lesbian, Gay, Bisexual, Transgender, and Queer Rights (RFSL), the normative divide concerning prostitution is apparently too great to permit full cooperation with organizations that support sex work. $^{31}$

Previous research has indicated that broad agendas can facilitate deliberation and be inclusive with respect to new members and perspectives, while narrower agendas and more strict frameworks tend to promote professionalization and enhance efficiency and operational focus (Boudreau 2010). Our findings illustrate the importance of the Platform's agenda in respect to inclusive membership insofar as the "victims-first" perspective makes possible a broad range of collaboration between diverse organizations, even though its support of client criminalization puts it at odds with the Rose Alliance. Support for the Swedish model of client criminalization thus reflects a degree of network closure, serves to narrow the organization, and excludes certain organizations that could be useful in relation to the "victims-first" agenda. The inclusion of the Rose Alliance and a pro-sex-worker perspective could potentially internalize conflicts concerning how to discuss trafficking and prostitution as well as possible solutions.

\section{Conflict management}

While the material we have examined reveals no overt differences that disrupt the activities of the Platform, perhaps because of the deliberate decision to exclude the pro-sex-worker perspective, a limited number of potentially problematic value conflicts can nevertheless be observed.

One issue concerns how to prioritize different types of human trafficking. While Swedish prostitution legislation primarily addresses the types of trafficking for sexual purposes to which mainly women are exposed, the Platform's agenda addresses the trafficking of all genders and age-groups. The sexual exploitation of women is the clear focus of certain members, such as radical feminist groups and women's shelters, but others are more concerned with child abuse or labor exploitation. ${ }^{32}$ Our respondents maintain that the Platform appears capable at the moment of dealing with such disparities, but acknowledge that there could be latent conflicts and the potential need for trade-offs.

Another possible source of conflict involves the ideological grounds for helping victims, which range from more radical feminist orientations to faith-based Christian commitments. There may well be multiple explanations for the absence of overt disagreements on this point. One key point commonly mentioned is that the current leadership is fully devoted to the Platform and to the principle of victims first, which supports previous research concerning how managers of activist coalitions navigate dangerous territory marked by diverse interests (Chemin and Vercher 2011). We add to this finding by suggesting that an atmosphere of distrust, in which conflicts of interest can arise, may be associated with the leadership being affiliated with a specific member organization. Neutral and devoted leadership could prove to be a successful approach to platform management in that it may serve to avert this problem. ${ }^{33}$

\footnotetext{
31 Ninna Mörner, interview 2; Nicklas Dennermalm, RFSL Stockholm, interview conducted October 26th, 2017.

32 Isabella Kim, interview; Karin Gynning, interview; Wiveca Holst, interview.

33 Ninna Mörner, interview 2; Madeleine Sundell, interview.
} 
Another potential factor in understanding the conflict-free environment of the Platform is that the latter is devoted to assisting the victims of trafficking in a nonprofit manner and does not promote the interests of any specific organizations. This altruistic focus, to which the various members contribute with the means at their disposal, provides a common basis for action as well as a sense of being part of something larger (compare Willems et al. 2017).

In addition, the strategy of permitting member organizations to decide which activities and programs they will support not only serves to maintain diversity and differing interests, it also helps avoid conflict. This is key evidence for the fruitfulness of the modular dimension of platforms, which makes strength and effectiveness possible regardless of diversity and competing agendas and interests. It is also significant that the various members are able to pursue their own agendas, thereby continuing with their own activities along with the activities of the Platform. The Platform thus does not replace existing organizations, but rather facilitates collaboration between them. This is another important indication of how the modularity of platforms has a positive effect upon both diversity and organizational efficiency.

In brief, the lack of conflict within the Platform appears to be related to its neutral leadership, altruistic focus, and voluntary participation in activities.

\section{Assessing the platform's internal coordination}

In summary, a diverse membership presents both challenges and opportunities within any collaborative arrangement. We find that the Platform has achieved effective internal coordination because of its high level of modularity, whereby it comprises a highly coordinated collective actor even as it allows for the flexibility and independence of its members. Its leadership has also succeeded in fostering trust among its varied participating organizations, which has made it possible to make the best use of its diverse members while promoting coordination between them. The differing levels of membership and the neutrality of its leadership are important factors in the Platform's avoidance of internal conflict and successful management of diversity. Members describe how the resulting close ties between them create flexible capacity, which has led to improved support in the ongoing efforts to help victims of trafficking. However, careful consideration is necessary in setting an appropriate agenda-although the broad altruistic goal of helping victims favors diversity regarding membership, support for client criminalization leads to exclusionary practices.

\section{External collaboration: managing the balance between trust and a critical voice}

\section{Public policy making}

Being engaged with the public authorities and becoming involved in policy making provides opportunities for CSOs to acquire influence and make an impact, although such activities nevertheless entail certain risks. A favorable condition for collaboration in the case we are investigating is the Platform's support for the Swedish model of client criminalization, which obviously facilitates the maintenance of close relations with the state. ${ }^{34}$

${ }^{34}$ Patrik Cederlöf, interview. 
Ninna Mörner acknowledged that agreement on this issue "makes it easier in pragmatic terms to coordinate efforts with public agencies and the government." 35

In respect to policy making and co-governance, the Platform has particularly been involved in the development and implementation of the National Referral Mechanism (NRM) and the National Support Program (NSP), both of which comprise a response to the critique raised toward Sweden in the 2013 GRETA report concerning the absence of collaboration with civil society actors. ${ }^{36}$ The newly established Platform quickly became a key partner of the National Coordinator in these activities by mediating contacts with civil society actors in relation to both their input and activities.

The NRM, which is a basic document for all public and private actors who are involved in the identification and support of victims of human trafficking, presents five detailed steps of action intended to ensure the efficient and secure referral, support, and protection of victims. It specifies the responsibilities that such public agencies as the police, prosecutors, social services, and the migration agency have regarding the support and protection of those who have been trafficked. It is noteworthy that civil society is explicitly assigned an important role in all five of these steps. ${ }^{37}$ Not only has the Platform thus had a basic input in the development of these guidelines, it has also assured that CSOs play a central role in the public management of the fight against human trafficking.

The Platform has exercised an even more prominent function in the development and management of the NSP, which was established in 2015 in order to overcome shortcomings in the public implementation of policies and programs aimed at protecting and supporting the victims of trafficking. ${ }^{38}$ One of the problems the NSP was intended to rectify concerned a specific legal practice that ran counter to international conventions, whereby victims were denied public support in Sweden during the minimum 30-day reflection period if they did not file a police report. ${ }^{39}$ While this problem had been identified by both the Platform ${ }^{40}$ and the Council of Europe, ${ }^{41}$ the National Task Force against Prostitution and Trafficking did not succeed in their efforts to design and implement a national support program in response. ${ }^{42}$ The National Coordinator subsequently delegated the task to the Platform in 2015 and made funding available for this purpose. The successful 2016 pilot program was extended, and since then, it has been managed by the Platform with national funding. ${ }^{43}$ The NSP has been very important from a victim's perspective in that it has made supplementary assistance available regarding housing, support for personal needs, and the possibility of safe return. The fact that this program was managed by the Platform after being

\footnotetext{
35 Ninna Mörner, interview 1.

36 GRETA, report 2014:11, page 55.

37 MMM English version, http://www.lansstyrelsen.se/Stockholm/SiteCollectionDocuments/Sv/publikatio ner/2016/R2016-29-national-referral-machanism-trafficking-webb.pdf, accessed 2017-09-11.

38 The NSP is temporarily on hold since January 2019, when the newly-established Gender Equality Agency assumed the coordination of efforts to combat trafficking in Sweden.

39 Ninna Mörner, interview 1.

40 Wiveca Holst, interview.

41 GRETA, report 2014:11.

42 The Swedish Agency for Public Management (SAPM), Utvärdering av samordningen av arbetet mot prostitution och människohandel vid Länsstyrelsen $i$ Stockholms län [Evaluation Report of the National Task Force Against Prostitution and Trafficking], 2014:14; Wiveca Holst, interview.

43 The Platform, https://manniskohandel.se/plattformen-civila-sverige-mot-manniskohandel/nationellt -stodprogram/, accessed 2017-09-06.
} 
designed in dialogue with the National Coordinator indicates the high level of trust and respect that has emerged between the Platform and public agencies.

In short, external collaboration between the Platform and public agencies has generated a number of policy documents that have been important for improving support for victims. While the degree of mutual trust that has been noted is clearly a prerequisite for such work, there are also indications that the Platform has preserved its critical voice. In addition, the Platform has reserved a significant role for CSOs in the victim referral mechanism, which has facilitated providing assistance to victims in accordance with international conventions.

\section{Public control}

The extensive collaboration that emerged between public authorities is evident by the fact that the Platform was delegated the task of managing the NSP even though the latter's funding is fully public. This includes the administration of a quality control system that has been developed and implemented by the Platform through which NGOs can apply for certification and thus obtain funding to support the victims in their care. ${ }^{44}$ The procedure involves specific criteria that must be met concerning work routines, methods, documentation, and staff training in order to help determine which applications are to be approved. Representatives from the Platform's NSP group make the final evaluation upon the basis of documentation and personal visits to the applicants, and already certified organizations are regularly reviewed. ${ }^{45}$ Furthermore, the Platform not only plays a high-level regulative role concerning actors who wish to join the NSP program, it is also the decision-making body in individual cases concerning applications for support. These decisions are taken by the Platform's NSP group and are reported to the National Coordinator on a regular basis. ${ }^{46}$ These activities reflect the responsibility for public control that has been delegated to the Platform, and also serve to guarantee quality in providing support for victims of trafficking.

The Platform also collects statistical data for public records. The organizations certified to participate in the NSP are in fact obliged to provide information concerning the individuals with whom they are in contact while preserving the latter's anonymity. Due to the specific nature of human trafficking, it is very difficult for public actors to gather information and generate statistics concerning victims, even though doing so is important for policy evaluation. The Platform and its member organizations have become an indispensable source of knowledge in this regard, not least for improving efforts to evaluate the effectivity of public policies and activities. ${ }^{47}$

Stated otherwise, the Platform has increased its influence over relevant public policy through the exercise of public control and thereby improved support for victims. The Platform seems aware of the potential risks of close collaboration with authorities and has been cautious to safeguard the integrity of individual victims. This strategy has been important for maintaining their role as an independent CSO, but there remains a potential risk that victims who distrust public agencies may hesitate to contact the Platform if they suspect that it is becoming too closely associated with the authorities.

\footnotetext{
44 Nationellt Stödprogram [National Support Program], Pilot Program (2015-2016), printed version.

45 Ida Elfving, UKV [Young Women's Defense Foundation], interview conducted November 23rd, 2017; Ninna Mörner, interview 2.

46 The Platform, https://manniskohandel.se/plattformen-civila-sverige-mot-manniskohandel/nationellt -stodprogram/, accessed 2017-12-20; Ninna Mörner, interview 1.

47 GRETA, report 2014:11.
} 


\section{Advocacy: a critical voice}

The Platform has clearly established itself as a viable and trustworthy partner by displaying operational capability on the ground. This is evident in the more practical activities that its members conduct either by themselves, or through coordination with other participating organizations, such as when a given organization calls for assistance in helping a victim. This has further contributed to the substantial leverage that the Platform enjoys in relation to politicians and the authorities, not least in those instances when it is displeased with the support that public agencies provide to victims of trafficking. One respondent thus maintains that

While public authorities consult the Platform concerning the fight against trafficking, we can also request a meeting with politicians and national authorities to discuss our concerns on our own initiative. This was not possible before we were a united platform. ${ }^{48}$

But is it possible to be a viable partner and collaborator and still sustain a critical perspective and voice? One reason why civil society is often viewed as indispensable in collaborative governance is precisely the fact that it plays an independent role. One of the Platform's board members explicitly remarks that its members in fact remain very active in this respect, stating that

We work actively to convey our views to key actors. As soon as we learn that activities or evaluations are underway, we take our chances and contact the people responsible in order to lobby for our perspectives and goals. ${ }^{49}$

The flexibility of platforms provides an important advantage insofar as it enables members to utilize their own organizations to critique public authorities in parallel with their engagement in the Platform's public activities. For example, a lawyer who is a board member states that she considers it to be an obligation on the part of her firm that they criticize the authorities when rules and regulations do not reflect the interests of her clients (victims), although they do not do so under the auspices of the Platform.

We oppose the migration board and the migration court on many issues, and over the years have critiqued various elements of the legal process when it does not work well for the parties we represent. ${ }^{50}$

It is noteworthy that one of our respondents maintains that the long tradition of an active civil society in Sweden makes it possible to strike a balance between receiving public funding and criticizing collaboration partners and official policies. ${ }^{51}$ The Platform appears to have been particularly successful in that it can serve as a respected and unified actor while also letting individual organizations act in their own interests.

\footnotetext{
48 Isabella Kim, interview.

49 Ibid.

${ }^{50}$ Karin Gyllenring, interview.

51 Wiveca Holst, interview.
} 


\section{Assessing the platform's external collaboration}

Our analysis indicates that the Platform indeed provides a crucial link between the contributions of civil society actors and regulation by public authorities upon the basis of legal frameworks. Public programs targeting victims have been improved by virtue of the involvement of the Platform in public policy development, the quality certification of shelters, and the provision of more reliable statistics for policy evaluation. The formalization of the Platform as an organization has been key to these activities insofar as networks, coalitions, and volunteer platforms can manage neither funding for a national support program nor certification. In addition, the Platform has to date been careful to safeguard the independence and critical public voice of CSOs in relation to public agencies. It has also explicitly provided them a role in the development of policy documents, which has helped nudge Sweden toward meeting the country's international obligations regarding the victims of trafficking. Moreover, the Platform continues to operate primarily upon the basis of volunteer resources and not public funding, which it receives only for financing the NSP. The long-term consequences of close collaboration with public authorities are difficult to assess, however, with the exercise of public control in particular being potentially problematic for the Platform's credibility.

\section{Conclusion}

While all forms of collaboration generate organizational and managerial problems, previous research has described both networks and hybrid models consisting of private actors and public authorities as promising organizational structures for addressing "wicked" social problems, not the least of these being trafficking and prostitution (Foot 2015; Lagon 2015; Wagenaar et al. 2017; Jones and Lutze 2016). This research has also discussed the challenges associated with group dynamics and conflicts of interests that affect collaborative anti-trafficking efforts (Foot 2015). The present study has explored the ability of (civil society) platforms to resolve the challenges facing internal and external collaboration in the effort to mitigate problems of coordination and collaboration, and our findings suggest that the platform organizational form may be useful for overcoming some of the challenges noted.

Upon the basis of recent theoretical and empirical discussions concerning platforms and collaborative governance (Ansell and Gash 2017; Selsky and Parker 2005; Furlan et al. 2014; Clear et al. 2018), we have investigated one particular platform - the Swedish Civil Society Platform against Human Trafficking - in order to explore the strengths and weaknesses of this organizational form. We argue that if platforms are to facilitate collaboration, then they must manage the diversity of their members in an optimal way and take into consideration the conflict between broad and narrow agendas in relation to the given goals. External collaboration is facilitated by the fact that a platform brings together a broad range of organizations, making it possible for them to speak and act as one. This provides a sound foundation for eventual collaboration with public agencies. But insofar as a platform is a type of CSO, it is important that both the platform as a whole and its individual member organizations preserve the integrity of their critical voices and continue to function as an opposition to politicians and public authorities. 
The potential of platforms relies upon the fact that their specific organizational structure appears to be particularly well suited for fostering internal and external collaboration, which in the case of the Platform are directly related to the improved support it provides to victims of trafficking. Its internal coordination is characterized by a high level of modularity - the various member organizations are diversified and complement each other, making it possible to provide victims with the full range of assistance needed in an effective way. Key factors in this regard are the Platform's graded membership policy and neutral leadership, which together facilitate maintaining a unified core while relieving members of the obligation to participate in all activities. This allows for both flexibility and specialization among the participating organizations and avoids rivalry in spite of their diversity, with the Platform's broad and altruistic "victims-first" agenda serving as an umbrella beneath which its varied members can gather.

The Platform's support for the official Swedish policy of client criminalization nevertheless constitutes a potential source of conflict to other civil society organizations and provides the ground for excluding pro-sex-worker organizations. We believe in this regard that the platform organization as such faces the need for a trade-off between, on the one hand, a broad and inclusive agenda that risks internalizing conflicts and thus hindering both internal and external collaboration, and, on the other, a narrow and exclusive agenda that advances effectiveness in the organization's activities.

In respect to external coordination, our study indicates that the Platform has fostered and substantially improved public-private collaboration as well as public support programs for victims. We find that while the Platform's statutory organizational form appears to have no bearing upon internal collaboration in any significant way, it clearly simplifies external collaboration to an important degree, with support for Sweden's official client criminalization policy easing collaboration with public authorities. In addition, we find that this organizational form has played a positive role in respect to advocacy, making it possible for the Platform to maintain its critical voice regardless of its close engagement with public authorities. In this regard, the platform's individual member organizations have been able to preserve their independence and flexibility even as they together comprise a collective actor and public partner. The Platform has also been careful to safeguard the integrity of victims in spite of its public undertakings. We must note, however, that the Platform's exercise of public management and control may undermine its status as an independent actor in the long run, which would hamper its ability to critique politicians and public agencies.

We should add that the findings of our study are primarily of heuristic and theoretical value and should thus be treated with some caution-a single case study such as ours may have examined a unique and particularly successful example. Although it is thus not possible in the strict sense to generalize our results empirically, our investigation has revealed certain organizational features of platforms that clearly deserve further exploration. Furthermore, platforms may function particularly well for CSOs that seek to join forces in seeking a resolution for a specific social/political problem through efforts directed toward assisting third parties under a common agenda. In other policy domains, however, or in cases where organizations promote the specific interests of their own members, such as trade unions, it may well be more difficult to form such coalitions.

We argue on the basis of our findings that platforms have the potential to provide a more solid basis than other forms of collaboration for efforts to combat such "wicked problems" as human trafficking insofar as they facilitate collaboration by means of a relatively broad agenda, whereby it is possible for differing actors and organizations to coordinate their various activities. These findings not only provide insights that are important for research 
concerning victims of trafficking, they also point to the need for more studies of the role of CSOs in the care and support of victims.

Acknowledgements Open access funding provided by Uppsala University. We wish to thank the three anonymous reviewers for careful reading and insightful comments on the article. We would also like to thank Andrew Blasko for assisting us with proofreading and language editing.

Funding No funding to report.

Open Access This article is licensed under a Creative Commons Attribution 4.0 International License, which permits use, sharing, adaptation, distribution and reproduction in any medium or format, as long as you give appropriate credit to the original author(s) and the source, provide a link to the Creative Commons licence, and indicate if changes were made. The images or other third party material in this article are included in the article's Creative Commons licence, unless indicated otherwise in a credit line to the material. If material is not included in the article's Creative Commons licence and your intended use is not permitted by statutory regulation or exceeds the permitted use, you will need to obtain permission directly from the copyright holder. To view a copy of this licence, visit http://creativecommons.org/licenses/by/4.0/.

\section{References}

Abbott, K. W., Levi-Faur, D., \& Snidal, D. (2017). Theorizing regulatory intermediaries. The ANNALS of the American academy of political and social science, 670(1), 14-35. https://doi.org/10.1177/00027 16216688272.

Ahn, R., Alpert, E. J., Purcell, G., Konstantopoulos, W. M., McGahan, A., Cafferty, E., et al. (2013). Human trafficking. American Journal of Preventive Medicine, 44(3), 283-289.

Andrews, R., Boyne, G. A., Meier, K. J., O’Toole, L. J., \& Walker, R. M. (2011). Environmental and organizational determinants of external networking. The American Review of Public Administration, 41(4), 355-374. https://doi.org/10.1177/0275074010382036.

Ansell, C., \& Gash, A. (2017). Collaborative platforms as a governance strategy. Journal of Public Administration Research and Theory, 28(1), 16-32. https://doi.org/10.1093/jopart/mux030.

Aronowitz, A. A. (2009). Human trafficking, human misery: The global trade in human beings. Westport, CT: Greenwood Publishing Group.

Baldwin, S. B., Eisenman, D. P., Sayles, J. N., Ryan, G., \& Chuang, K. S. (2011). Identification of human trafficking victims in health care settings. Health and Human Rights, 13(1), e36-e49.

Black, J. (2008). Constructing and contesting legitimacy and accountability in polycentric regulatory regimes. Regulation and Governance, 2(2), 137-164. https://doi.org/10.1111/j.1748-5991.2008.00034 .x.

Boudreau, K. (2010). Open platform strategies and innovation: Granting access vs. devolving control. Management Science, 56(10), 1849-1872.

Carter, D. P., \& Mahallati, N. (2017). Coordinating intermediaries: The prospects and limitations of professional associations in decentralized regulation. Regulation and Governance. https://doi.org/10.1111/ rego.12167.

Chang, G., \& Kim, K. (2007). Reconceptualizing approaches to human trafficking: New directions and perspectives from the field. Stanford Journal of Civil Rights and Civil Liberties, 3(2), 1-27.

Chemin, C., \& Vercher, C. (2011). The challenge of activist coalition governance: Accommodating diversity to create institutions: An approach via the inter-relationships between action, project and instrument. VOLUNTAS: International Journal of Voluntary and Nonprofit Organizations, 22(4), 682-705. https:// doi.org/10.1007/s11266-011-9201-9.

Cho, S. Y., Dreher, A., \& Neumayer, E. (2014). Determinants of anti-trafficking policies: Evidence from a new index. The Scandinavian Journal of Economics, 116(2), 429-454.

Ciborra, C. U. (1996). The platform organization: Recombining strategies, structures, and surprises. Organization Science, 7(2), 103-118.

Clear, A., Megan, P., \& David, H. (2018). Nonprofit advocacy tactics: Thinking inside the box? VOLUNTAS: International Journal of Voluntary and Nonprofit Organizations, 29(4), 857-869. https://doi. org/10.1007/s11266-017-9907-4. 
Cristofoli, D., Meneguzzo, M., \& Riccucci, N. (2017). Collaborative administration: The management of successful networks. Public Management Review, 19(3), 275-283. https://doi.org/10.1080/14719 037.2016 .1209236

Davy, D. (2013a). Understanding the motivations and activities of transnational advocacy networks against child sex trafficking in the Greater Mekong Subregion: The value of cosmopolitan globalization theory. Cosmopolitan Civil Societies: An Interdisciplinary Journal, 5(1), 39-68.

Davy, D. (2013b). Measuring the immeasurable: Understanding the effectiveness of anti-child trafficking transnational advocacy networks. Cosmopolitan Civil Societies: An Interdisciplinary Journal, 5(2), 84-113.

Dodillet, S. (2009). Är sex arbete? Svensk och tysk prostitutionspolitik sedan 1970- talet. Stockholm/Sala: Vertigo.

Ferlie, E., Fitzgerald, L., McGivern, G., Dopson, S., \& Bennett, C. (2011). Public policy networks and 'wicked problems': A nascent solution? Public Administration, 89(2), 307-324. https://doi.org/10.11 11/j.1467-9299.2010.01896.x.

Erikson, J. (2017). Criminalising the client. Institutional change, gendered ideas, and feminist strategies. New York: Rowman and Littlefield International.

Erikson, J., \& Larsson, O. L. (2019). Beyond client criminalization: Analyzing collaborative governance arrangements for combatting prostitution and trafficking in Sweden. Regulation \& Governance. https:// doi.org/10.1111/rego.12259.

Foot, K. (2015). Collaborating against human trafficking: Cross-sector challenges and practices. Lanham, MD: Rowman and Littlefield.

Furlan, A., Cabigiosu, A., \& Camuffo, A. (2014). When the mirror gets misted up: Modularity and technological change. Strategic Management Journal, 35(6), 789-807.

Gallagher, A. T. (2010). The international law of human trafficking. Cambridge: Cambridge University Press.

Goodey, J. (2008). Human trafficking: Sketchy data and policy responses. Criminology and Criminal Justice, 8(4), 421-442.

Guild, E. (2006). Immigration and criminal law in the European Union: The legal measures and social consequences of criminal law in member states on trafficking and smuggling in human beings. In E. Guild \& P. Minderhoud (Eds.), Immigration and criminal law in the European Union: The legal measures and social consequences of criminal law in member states on trafficking and smuggling in human beings (pp. 1-6). Leiden: Brill.

Halley, J., Kotiswaran, P., Shamir, H., \& Thomas, C. (2006). From the international to the local in feminist legal responses to rape, prostitution/sex work, and sex trafficking: four studies in contemporary governance feminism. Harvard Journal of Law and Gender, 29(2), 335.

Hughes, D. M. (2004). Best practices to address the demand side of sex trafficking. Rhode Island: University of Rhode Island.

Huxham, C., \& Vangen, S. (2013). Managing to collaborate: The theory and practice of collaborative advantage. Abingdon: Routledge.

Jones, L., Engstrom, D. W., Hilliard, T., \& Diaz, M. (2007). Globalization and human trafficking. Journal of Sociology and Social Welfare, 34(2), 107.

Jones, T. R., \& Lutze, F. E. (2016). Anti-human trafficking interagency collaboration in the state of Michigan: An exploratory study. Journal of Human Trafficking, 2(2), 156-174.

Kania, J., \& Kramer, M. (2011). Collective impact. Stanford Social Innovation Review, 9(1), 36-41.

Klijn, E. H., Edelenbos, J., \& Steijn, B. (2010). Trust in governance networks: Its impacts on outcomes. Administration and So ciety, 42(2), 193-221.

Klijn, E. H., \& Koppenjan, J. (2016). Governance networks in the public sector. Abingdon: Routledge.

Kotrla, K. (2010). Domestic minor sex trafficking in the United States. Social Work, 55(2), 181-187. https:// doi.org/10.1093/sw/55.2.181.

Lagon, M. P. (2015). Traits of transformative anti-trafficking partnerships. Journal of Human Trafficking, $1(1), 21-38$.

Larsson, O. (2019). A theoretical framework for analyzing institutionalized domination in network governance arrangements. Critical Policy Studies, 13(1), 81-100. https://doi.org/10.1080/19460 171.2017.1393440.

Lederer, L. J., \& Wetzel, C. A. (2014). The health consequences of sex trafficking and their implications for identifying victims in healthcare facilities. Annals of Health Law, 23(1), 61.

Levy, J., \& Jakobsson, P. (2013). Abolitionist feminism as patriarchal control: Swedish understandings of prostitution and trafficking. Dialectical Anthropology, 37(2), 333-340. 
Magis, K. (2010). Convergence: Finding collective voice in global civil society. VOLUNTAS: International Journal of Voluntary and Nonprofit Organizations, 21(3), 317-338. https://doi.org/10.1007/s1126 6-009-9107-y.

Mati, J. M. (2009). A cartography of a global civil society advocacy alliance: The case of the global call to action against poverty. Journal of Civil Society, 5(1), 83-105. https://doi.org/10.1080/1744868090 2925661.

Nambisan, S. (2009). Platforms for collaboration. Stanford Social Innovation Review, 7(3), 44-49.

O'Toole, L. J., \& Meier, K. J. (2004). Desperately seeking Selznick: Cooptation and the dark side of public management in networks. Public Administration Review, 64(6), 681-693.

Outshoorn, J. (2005). The political debates on prostitution and trafficking of women. Social Politics: International Studies in Gender, State and Society, 12(1), 141-155.

Provan, K. G., \& Kenis, P. (2008). Modes of network governance: structure, management, and effectiveness. Journal of Public Administration Research and Theory, 18(2), 229-252.

Rhodes, R. A. W. (1996). The new governance: Governing without government. Political Studies, 44(4), 652-667.

Selsky, J. W., \& Parker, B. (2005). Cross-sector partnerships to address social issues: Challenges to theory and practice. Journal of Management, 31(6), 849-873. https://doi.org/10.1177/0149206305279601.

Showden, C. R., \& Majic, S. (2014). Negotiating sex work: Unintended consequences of policy and activism. Minneapolis: University of Minnesota Press.

Skilbrei, M., \& Holmström, C. (2017). Linking prostitution and human trafficking policies: The nordic experience. In H. Nelen \& D. Siegel (Eds.), Contemporary organized crime: Developments, challenges and responses (pp. 65-79). Cham: Springer.

Steijn, B., Klijn, E. H., \& Edelenbos, J. (2011). Public private partnerships: Added value by organizational form or management? Public Administration, 89(4), 1235-1252. https://doi.org/10.111 $1 / j .1467-9299.2010 .01877 . x$.

Steins, N. A., \& Edwards, V. M. (1999). Platforms for collective action in multiple-use common-pool resources. Agriculture and Human Values, 16(3), 241-255.

Torenvlied, R., Akkerman, A., Meier, K. J., \& O'Toole, L. J. (2013). The multiple dimensions of managerial networking. The American Review of Public Administration, 43(3), 251-272. https://doi. org/10.1177/0275074012440497.

van der Heijden, M., \& Schalk, J. (2018). Making good use of partners: Differential effects of managerial networking in the social care domain. International Public Management Journal, 21(5), 729-759. https://doi.org/10.1080/10967494.2016.1199449.

Verweij, S., Klijn, E. H., Edelenbos, J., \& Van Buuren, A. (2013). What makes governance networks work? A fuzzy set qualitative comparative analysis of 14 Dutch spatial planning projects. Public Administration, 91(4), 1035-1055.

Wagenaar, H., Amesberger, H., \& Altink, S. (2017). Designing prostitution policy. Bristol: Bristol University Press.

Weber, E. P., \& Khademian, A. M. (2008). Wicked problems, knowledge challenges, and collaborative capacity builders in network settings. Public Administration Review, 68(2), 334-349.

Weitzer, R. (2011). Sex trafficking and the sex industry: The need for evidence-based theory and legislation. The Journal of Criminal Law and Criminology, 101(4), 1337-1369.

Willems, J., Andersson, F. O., Jegers, M., \& Renz, D. O. (2017). A coalition perspective on nonprofit governance quality: Analyzing dimensions of influence in an exploratory comparative case analysis. VOLUNTAS: International Journal of Voluntary and Nonprofit Organizations, 28(4), 1422-1447. https:// doi.org/10.1007/s11266-016-9683-6.

Ysa, T., Sierra, V., \& Esteve, M. (2014). Determinants of network outcomes: The impact of management strategies. Public Administration, 92(3), 636-655. https://doi.org/10.1111/padm.12076.

Publisher's Note Springer Nature remains neutral with regard to jurisdictional claims in published maps and institutional affiliations. 